\title{
Biochar in Nutrient Recycling-The Effect and Its Use in Wastewater Treatment
}

\author{
Bente Foereid \\ Bioforsk-Norwegian Institute for Agricultural and Environmental Research, Ås, Norway \\ Email: bente.foreid@bioforsk.no
}

Received 7 January 2015; accepted 26 January 2015; published 27 January 2015

Copyright (C) 2015 by author and Scientific Research Publishing Inc.

This work is licensed under the Creative Commons Attribution International License (CC BY). http://creativecommons.org/licenses/by/4.0/

(c) (i) Open Access

\begin{abstract}
Biochar, i.e. charred organic material, appears to increase nutrient retention in soil. The mechanism for how this happens is not clear. Here two possible mechanisms, adsorption and microbial immobilisation, are suggested and compared. It is also suggested that we use biochar in wastewater treatment, and so potentially integrate it better into the total waste management cycle.
\end{abstract}

\section{Keywords}

\section{Biochar, Nutrients, Wastewater Treatment}

\section{Introduction}

Increase in population and relative wealth has led to a greater demand for food. Population growth is estimated to continue at a slowing rate until about 2100 and peak at about 10.1 billion [1]. It is projected that agriculture can supply enough food for the growing population, but at a cost to the environment [2] [3]. In the future, we will need to increase agricultural production without increasing and ideally decreasing environmental impacts. Furthermore, in the future, farmland will need to serve multiple purposes, such as carbon storage in addition to food production.

Many of the adverse environmental impacts on agriculture are caused by the use of nitrogen fertilizers [4] [5]. In turn, many waste products, including sewage and animal waste are rich in nutrients and should be used as fertilizers in agriculture to close the nitrogen cycle as much as possible. This would reduce pollution and reduce the need to use energy intensive mineral fertilizers. Mineral nitrogen occurs in soil in two forms: ammonium and nitrate [6]. In agriculture, soil microbial transformation of ammonium into more soluble and mobile nitrate (nitrification) is usually quick. Nitrogen is lost from agricultural systems principally by leaching of nitrate, but also to some extent through leaching of ammonium and gaseous losses.

Biochar is usually defined as charred organic material used as a soil amendment [7] [8]. It is promoted as a 
way to increase storage of carbon in the soil [9]. There are also reports of biochar applications having agronomic benefits, particularly on nutrient use efficiency, crop yield and reduced leaching losses [10]-[15] and pollutant immobilization [16]. However, no effect or even opposite effects have also been reported, so biochar remains a controversial issue [17]. Varying results may be expected as there are many types of biochar (different feedstock and production temperature and time) and many conditions under which it is applied (soil type, climate and crop type). To be able to give meaningful advice to farmers and other practitioners on whether to apply biochar and what type of biochar to use, a mechanistic understanding of how biochar works and interacts with other soil factors is necessary.

\section{What Is the Mechanism for Biochar Effect?}

Whilst some of the short term effects observed upon biochar application may be explained by pH changes [18], or direct release of nutrients and other substances from the biochar itself [19], the longer-term effects are almost certainly explained by its porous structure and large internal surface area, in a similar way as activated carbon that has been used as an adsorbent for water purification for a long time [20].

The most direct explanation for the effect of biochar on nutrient retention is that it acts as an adsorbent [13]. Adsorption is a phenomenon that occurs at the interface between a liquid and solid phase with the formation of bonds between the surface of solid phase and molecules present in liquid phase [20]. Organic material generally has some adsorption capacity, and charring the material usually increases the adsorption capacity [21]. Most evidence suggests that biochar adsorbs more cations than anions, and several experiments have shown removal of ammonium from aqueous solution [22]-[24]. Gaseous ammonia also adsorbs to biochar, and this ammonia is available to plants [25] [26]. Biochar has also been shown to increase cation exchange capacity in soil [27], and it is therefore likely that biochar can reduce leaching of ammonium and store it in a plant available form in the soil. Most studies suggest little or no adsorption of nitrate, although some adsorption has been observed with some high temperature biochars [22] [28]. Applied ammonium usually reacts quickly to form nitrate in agricultural soils, and nitrate is easily lost through leaching. It is possible that this process can be stopped if the applied released ammonium is quickly adsorbed to soil or biochar particles. Only if all the applied nitrogen is in the form of nitrate, it becomes difficult to explain the effect on nitrogen leaching through adsorption.

In addition to adsorption, biochar may also affect nutrient cycles in soil through microbial processes, in the sense that microbial biomass could act as a storage pool for nutrients, i.e. substances that microbes preferentially take up [29] [30]. Biochar may enhance microbial growth by providing pores as refuges or just larger surfaces to grow on [31] [32]. This may explain why increased plant growth is sometimes only observed a few years after the application of biochar [11]. If this mechanism is at play, both nitrate and ammonium could be immobilized, as both can be taken up by microbes. The nitrogen in microbial biomass is probably not directly available to plants, but may become available as the microbes die, and plants or their mycorrhiza may be able to stimulate this release in some way [33]-[35]. It is also possible that microbial processes and adsorption can interact; microbes may be better able to utilize nutrients adsorbed to the surfaces they grow on, but this has not been investigated.

Soil types and their suitability for cropping have been studied for more than a century, but the research has focused more on the impact which different types of soil have on cropping rather than understanding the underlying mechanisms. It is well known that nitrogen losses tend to be greater from light sandy soils than from clay soils, and that clay soils usually have more carbon and nitrogen stored in organic form [36]-[38]. Clay soils also have higher internal surface area and cation exchange capacity than sandy soils [39]. There is also evidence that the difference between soil textures is related to pore structure [40] [41]. The effect of adding biochar may therefore be similar to that of increasing clay content. If this is the case, it would be expected that biochar would have a stronger effect in sandy soils than in clay soils. This was also found by Liu et al. [15] in a meta-analysis and by Zheng et al. [42] when comparing two soils.

\section{Possibilities for Biochar in Wastewater Treatment}

Biochar has so far mainly been promoted as a soil amendment, but as a good adsorbent, it may also hold promise in low cost wastewater treatment. Activated carbon is already being used, but biochars may form a lower cost alternative. Several authors have found that biochar can remove various heavy metals [16] [43]-[47], phosphorous [24] [48], and as already discussed, nitrogen from solution. Biochar could potentially be used to adsorb nu- 
trients from wastewater, and then the loaded biochar or mixture of sludge and biochar could be added to soil. Digestate from anaerobic digestion of sewage sludge, manure and residues from the food/beverage or agricultural industry usually contains high levels of nutrients which makes it suitable for utilization as an organic soil fertilizer [49]. Using biochar to extract and concentrate the nutrients could eliminate current difficulties associated with the storage of high volumes of the digestate and other waste liquids, and also eliminate environmental concerns relating to spreading the high volumes of liquid fertilizer on soil. In some wastewaters, adsorption of heavy metals and other harmful substances in addition to nutrient could be a problem, but in the case of farm waste or residues from the food beverage industry it should be safe.

\section{Benefits of Pre-Loading with Nutrients}

There is evidence that biochar increases nutrient retention [7] [8] [10]-[14] [17] [18] [22] in soil and that it can absorb nutrients from solution. This opens the possibility of using biochar as an adsorbent in wastewater treatment and then applying the biochar. It is possible that such "pre-loading" with nutrients could have additional benefits compared to adding biochar nutrient-rich wastewater separately, but this has not been investigated.

There are some reports that suggest that adding biochar to farm waste during storage and "pre-loading" it with nutrients may be beneficial compared to adding both separately to soil [50] [51]. Sarkhot et al. [52] found that added biochar pre-loaded with manure has many advantages compared to adding only biochar, but did not compare it to adding both separately. If there is an advantage in terms of nitrogen-use efficiency in pre-adsorbing nitrogen to biochar compared to adding both separately, it further strengthens the case for using biochar in wastewater treatment. Better understanding of the importance of adsorption and microbial immobilization as mechanisms for biochar effect, as well as possible interactions between the two, is necessary to predict the effect of "pre-loading" biochar with nutrients.

\section{Recommendations for Future Work}

The mechanism(s) for biochar effect on nutrient retention needs to be resolved. To distinguish between adsorption and microbial uptake as mechanisms, one can take advantage of the fact that most biochar do not adsorb nitrate [22] [53]. If microbial immobilization is the main mechanism, retention of nitrate and ammonium nitrogen will be similar. If there is no effect at all on retention of nitrogen added as nitrate, adsorption would be the mechanism, intermediate results would support some sorts of interaction.

Furthermore, if pre-loading of biochar with nutrients can have benefits compared to adding both separately, this would further strengthen the case for integrating biochar into the wastewater management system. This question can be investigated by applying biochar pre-adsorbed with labelled nitrogen and comparing it to the same amount of biochar and labelled nitrogen applied separately.

\section{Acknowledgements}

The author wishes to thank Dr. Alessio Cibati and Dr. Joseph Akunna for useful discussions. Three reviewers are acknowledged for useful suggestions.

\section{References}

[1] Population Division, Department of Economic and Social Affairs, United Nations (2011) World Population Prospects: The 2010 Revision, Highlights and Advance Tables. United Nations, Working Paper No. ESA/P/WP.220.

[2] Evans, L.T. (1998) Feeding the Ten Billion-Plants and Population Growth. Cambridge University Press, Cambridge.

[3] Godfray, H.C.J., Beddington, J.R., Crute, I.R., Haddad, L., Lawrence, D., Muir, J.F., et al. (2010) Food Security: The Challenge of Feeding 9 Billion People. Science, 327, 812-818. http://dx.doi.org/10.1126/science.1185383

[4] Vitousek, P.M., Aber, J.D., Howarth, R.W., Likens, G.E., Matson, P.A., Schindler, D.W., et al. (1997) Human Alteration of the Global Nitrogen Cycle: Sources and Consequences. Ecological Applications, 7, 737-750.

[5] Galloway, J.N., Dnetener, F.J., Capone, D.G., Boyer, E.W., Howarth, R.W., Seitzinger, S.P., et al. (2004) Nitrogen Cycles: Past, Present, and Future. Biogeochemistry, 70, 153-226. http://dx.doi.org/10.1007/s10533-004-0370-0

[6] MacDonald, J.G. and Nielsen, D.R. (1978) Nitrogen in the Environment. Volume 1: Nitrogen Behaviour in Field Soil. Academic Press.

[7] Lehmann, J. and Rondon, M. (2006) Bio-Char Soil Management on Highly Weathered Soils in the Humid Tropics. In: 
Uphoff, N., Ed., Biological Approaches to Sustainable Soil Systems, CRC Press, Boca Raton, 517-530. http://dx.doi.org/10.1201/9781420017113.ch36

[8] Lehmann, J. and Joseph, S. (2009) Biochar for Environmental Management: Science and Technology. Earthscan, London.

[9] Woolf, D., Amonette, J.E., Street-Perrott, F.A., Lehmann, J. and Joseph, S. (2010) Sustainable Biochar to Mitigate Global Climate Change. Nature Communications, 1, Article No. 56.

[10] Lehmann, J., da Silva Jr., J.P., Steiner, C., Nehls, T., Zech, W. and Glaser, B. (2003) Nutrient Availability and Leaching in an Archaeological Anthrosol and a Ferralsol of the Central Amazon Basin: Fertilizer, Manure and Charcoal Amendments. Plant and Soil, 249, 343-357. http://dx.doi.org/10.1023/A:1022833116184

[11] Major, J., Rondon, M., Molina, D., Riha, S.J. and Lehmann, J. (2010) Maize Yield and Nutrition during 4 Years after Biochar Application to a Columbian Savanna Oxisol. Plant and Soil, 333, 117-128. http://dx.doi.org/10.1007/s11104-010-0327-0

[12] Knowles, O.A., Robinson, B.H., Contangelo, A. and Clucas, L. (2011) Biochar for Mitigation of Nitrate Leaching from Soil Amended with Biosolids. Science of the Total Environment, 409, 3206-3210. http://dx.doi.org/10.1016/j.scitotenv.2011.05.011

[13] Clough, T.J., Condron, L.M., Kamman, C. and Muller, C. (2013) A Review of Biochar and Soil Nitrogen Dynamics. Agronomy, 3, 275-293. http://dx.doi.org/10.3390/agronomy3020275

[14] Zheng, H., Wang, Z., Deng, X., Herbert, S. and Xing, B. (2013) Impacts of Adding Biochar on Nitrogen Retention and Bioavailability in Agricultural Soil. Geoderma, 206, 32-39. http://dx.doi.org/10.1016/j.geoderma.2013.04.018

[15] Liu, X., Zhang, A., Joseph, C.J.S., Bian, R., Li, L., Pan, G. and Paz-Ferreiro, J. (2013) Biochar's Effect on Crop Productivity and the Dependence on Experimental Conditions-A Meta-Analysis of Literature Data. Plant and Soil, $\mathbf{3 7 3 ,}$ 583-594. http://dx.doi.org/10.1007/s11104-013-1806-x

[16] Beesley, L., Moreno-Jiménez, E., Gomez-Eyles, J.L., Harris, E., Robinson, B. and Sizmur, T. (2011) A Review of Biochars' Potential Role in the Remediation, Revegetation and Restoration of Contaminated Soils. Environmental Pollution, 159, 3269-3282. http://dx.doi.org/10.1016/j.envpol.2011.07.023

[17] Spokas, K.A., Cantrell, K.B., Novak, J.M., Archer, D.W., Ippolito, J.A., Collins, H.P., et al. (2012) Biochar: A Synthesis of Its Agronomic Impact beyond Carbon Sequestration. Journal of Environmental Quality, 41, 973-989. http://dx.doi.org/10.2134/jeq2011.0069

[18] Van Zwieten, L., Kimber, S., Morris, S., Chan, K., Downie, A., Rust, J., et al. (2010) Effects of Biochar from Slow Pyrolysis of Papermill Waste on Agronomic Performance and Soil Fertility. Plant and Soil, 327, 235-246. http://dx.doi.org/10.1007/s11104-009-0050-x

[19] Smith, J.L., Collins, H.P. and Bailey, V.L. (2010) The Effect of Young Biochar on Soil Respiration. Soil Biology \& Biochemistry, 42, 2345-2347. http://dx.doi.org/10.1016/j.soilbio.2010.09.013

[20] Gray, N.F. (1999) Water Technology: An Introduction for Scientists and Engineers. Arnold, London, 548 p.

[21] Bhatnagar, A. and Sillanpaa, M. (2010) Utilization of Agro-Industrial and Municipal Waste Materials as Potential Adsorbents for Water Treatment: A Review. Chemical Engineering Journal, 157, 277-296. http://dx.doi.org/10.1016/j.cej.2010.01.007

[22] Yao, Y., Gao, B., Zhang, M., Inyang, M. and Zimmermann, A.R. (2012) Effect of Biochar Amendment on Sorption and Leaching of Nitrate, Ammonium, and Phosphate in a Sandy Soil. Chemosphere, 89, 1467-1471. http://dx.doi.org/10.1016/j.chemosphere.2012.06.002

[23] Dempster, D.N., Gleeson, D.B., Solaiman, Z.M., Jones, D.L. and Murphy, D.V. (2012) Decreased Soil Microbial Biomass and Nitrogen Mineralisation with Eucalyptus Biochar Addition to a Coarse Textured Soil. Plant and Soil, 354, 311-324. http://dx.doi.org/10.1007/s11104-011-1067-5

[24] Hollister, C.C., Bisogni, J.J. and Lehmann, J. (2012) Ammonium, Nitrate, and Phosphate Sorption to and Solute Leaching from Biochars Prepared from Corn Stover (Zea mays L.) and Oak Wood (Quercus spp.). Journal of Environmental Quality, 1, 137-144.

[25] Taghizadeh-Toosi, A., Clough, T.J., Sherlock, R.R. and Condron, L.M. (2012) A Wood Based Low Temperature Biochar Captures $\mathrm{NH}_{3}-\mathrm{N}$ Generated from Ruminant Urine-N, Retaining Its Bioavailability. Plant and Soil, 353, 73-84. http://dx.doi.org/10.1007/s11104-011-1010-9

[26] Taghizadeh-Toosi, A., Clough, T.J., Sherlock, R.R. and Condron, L.M. (2012) Biochar Adsorbed Ammonia Is Bioavailable. Plant and Soil, 350, 57-69. http://dx.doi.org/10.1007/s11104-011-0870-3

[27] Liang, B., Lehmann, J., Solomon, D., Kinyangi, J., Grossman, J., O’Neill, B., et al. (2006) Black Carbon Increases Cation Exchange Capacity in Soils. Soil Science Society American Journal, 70, 1719-1730. http://dx.doi.org/10.2136/sssaj2005.0383

[28] Mizuta, K., Matsumoto, T., Hatate, Y., Nishihara, K. and Nakanishi, T. (2004) Removal of Nitrate-Nitrogen from Drink- 
ing Water Using Bamboo Powder Charcoal. Bioresource Technology, 95, 255-257. http://dx.doi.org/10.1016/j.biortech.2004.02.015

[29] Lehmann, J., Rillig, M.C., Thies, J., Masiello, C.A., Hockaday, W.C. and Crowley, D. (2011) Biochar Effects on Soil Biota: A Review. Soil Biology and Biochemistry, 43, 1812-1836. http://dx.doi.org/10.1016/j.soilbio.2011.04.022

[30] Güereña, D.T., Lehmann, J., Hanley, K., Enders, A., Hyland, C. and Riha, S. (2013) Nitrogen Dynamics Following Field Application of Biochar in a Temperate North American Maize-Based Production System. Plant and Soil, 365, 239-254. http://dx.doi.org/10.1007/s11104-012-1383-4

[31] Steiner, C., Glaser, B., Teixaira, W.G., Lehmann, J., Blum, W.E.H. and Zech, W. (2008) Nitrogen Retention and Plant Uptake on a Highly Weathered Central Amazonian Ferralsol Amended with Compost and Charcoal. Journal of Plant Nutrition and Soil Science, 171, 893-899. http://dx.doi.org/10.1002/jpln.200625199

[32] Steinbiss, S., Gleixner, G. and Antonietti, M. (2009) Effect of Biochar on Soil Carbon Balance and Soil Microbial Activity. Soil Biology \& Biochemistry, 41, 1301-1310. http://dx.doi.org/10.1016/j.soilbio.2009.03.016

[33] Robinson, D., Griffiths, B., Ritz, K. and Wheatley, R. (1989) Root-Induced Nitrogen Mineralisation: A Theoretical Analysis. Plant and Soil, 117, 185-193. http://dx.doi.org/10.1007/BF02220711

[34] Liljeroth, E., Baath, E., Mathasson, I. and Lundborg, T. (1990) Root Exudation and Rhizoplane Bacterial Abundance of Barley (Hordeum vulgare L.) in Relation to Nitrogen Fertilisation and Root Growth. Plant and Soil, 127, 81-89. http://dx.doi.org/10.1007/BF00010839

[35] Liljeroth, E., Kuikman, P. and Van Veen, J.A. (1994) Carbon Translocation to the Rhizospere of Maize and Wheat and Influence on the Turnover of Native Soil Organic Matter at Different Soil Nitrogen Levels. Plant and Soil, 161, 233240. http://dx.doi.org/10.1007/BF00046394

[36] Parton, W.J., Schimel, D.S., Cole, C.V. and Ojima, D.S. (1987) Analysis of Factors Controlling Soil Organic-Matter Levels in Great-Plains Grasslands. Soil Science Society of America Journal, 51, 1173-1179. http://dx.doi.org/10.2136/sssaj1987.03615995005100050015x

[37] Parton, W.J., Ojima, D.S., Cole, C.V., Bryant, R.B. and Arnold, R.W. (1994) A General Model for Soil Organic Matter Dynamics: Sensitivity to Litter Chemistry, Texture and Management. In: Bryant, R.B. and Arnold, R.W., Eds., Quantitative Modeling of Soil Forming Processes, Soil Science Society of America, Madison, 147-167.

[38] Schmidt, M.W.I., Torn, M.S., Abiven, S., Dittmar, T., Guggenberger, G., Janssens, I.A., Kleber, M., Kögel-Knabner, I., Lehmann, J., Manning, D.A.C., Nannipieri, P., Rasse, D.P., Weiner, S. and Trumbore, S.E. (2011) Persistence of Soil Organic Matter as an Ecosystem Property. Nature, 478, 49-56. http://dx.doi.org/10.1038/nature10386

[39] Osman, K.T. (2013) Soils: Principles, Properties and Management. Springer, Dordrecht. http://dx.doi.org/10.1007/978-94-007-5663-2

[40] Strong, D.T., De Wever, H., Merckx, R. and Recous, S. (2004) Spatial Location of Carbon Decomposition in the Soil Pore System. European Journal of Soil Science, 55, 739-750. http://dx.doi.org/10.1111/j.1365-2389.2004.00639.x

[41] Sleutel, S., Bouckaert, L., Buchan, D., Van Loo, D., Cornelis, W.M. and Sanga, H.G. (2012) Manipulation of the Soil Pore and Microbial Community Structure in Soil Mesocosm Incubation Studies. Soil Biology \& Biochemistry, 45, 40- 48. http://dx.doi.org/10.1016/j.soilbio.2011.09.016

[42] Zheng, J., Stewart, C.E. and Cotrufo, F. (2012) Biochar and Nitrogen Fertilizer Alters Nitrogen Dynamics and Greenhouse Gas Fluxes from Two Temperate Soils. Journal of Environmental Quality, 41, 1361-1370.

[43] Beesley, L. and Marmiroli, M. (2011) The Immobilisation and Retention of Soluble Arsenic, Cadmium and Zink by Biochar. Environmental Pollution, 159, 474-480. http://dx.doi.org/10.1016/j.envpol.2010.10.016

[44] Chen, X.C., Chen, G.C., Chen, L.G., Chen, Y.X., Lehmann, J., McBride, M.B. and Hay, A.G. (2011) Adsorption of Copper and Zinc by Biochars Produced from Pyrolysis of Hardwood and Corn Straw in Aqueous Solution. Bioresource Technology, 102, 8877-8884. http://dx.doi.org/10.1016/j.biortech.2011.06.078

[45] Uchimiya, M., Klasson, T.K., Wartelle, L.H. and Lima, I.M. (2011) Influence of Soil Properties on Heavy Metal Sequestration by Biochar Amendment: 1. Copper Sorption Isotherms and Release of Cations. Chemosphere, 82, 1431- 1437. http://dx.doi.org/10.1016/j.chemosphere.2010.11.050

[46] Inyang, M., Gao, B., Yao, Y., Xue, Y.W., Zimmermann, A.R., Pullammanappalill, P. and Cao, X.D. (2012) Removal of Heavy Metals from Aqueous Solution by Biochars Derived from Anaerobically Digested Biomass. Bioresource Technology, 110, 50-56. http://dx.doi.org/10.1016/j.biortech.2012.01.072

[47] Kolodynska, D., Wnetrzak, R., Leahy, J.J., Hayes, M.H.B., Kwapinski, W. and Hubicki, Z. (2012) Kinetic and Adsorptive Characterization of Biochar in Metal Ions Removal. Chemical Engineering Journal, 197, 295-305. http://dx.doi.org/10.1016/j.cej.2012.05.025

[48] Yao, Y., Gao, B., Inyang, M., Zimmermann, A.R., Cao, X.D., Pullammanappallil, P. and Yang, L.Y. (2011) Biochar Derived from Anaerobically Digested Sugar Beet Tailings: Characterization and Phosphate Removal Potential. Bioresource 
Technology, 102, 6273-6278. http://dx.doi.org/10.1016/j.biortech.2011.03.006

[49] Abdullahi, Y.A., Akunna, J.C., White, N.A., Hallett, P.D. and Wheatley, R. (2008) Investigating the Effects of Anaerobic and Aerobic Post-Treatment on Quality and Stability of Organic Fraction of Municipal Solid Waste as Soil Amendment. Bioresource Technology, 99, 8631-8636. http://dx.doi.org/10.1016/j.biortech.2008.04.027

[50] Schmidt, H.-P. (2012) Treating Liquid Manure with Biochar. Ithaka Journal, 1, 273-276.

[51] Schmidt, H.-P. (2012) 55 Uses of Biochar. Ithaka Journal, 1, 286-289.

[52] Sarkhot, D.V., Berhe, A.A. and Ghezzehei, T.A. (2012) Impact of Biochar Enriched with Dairy Manure Effluent on Carbon and Nitrogen Dynamics. Journal of Environmental Quality, 41, 1107-1114. http://dx.doi.org/10.2134/jeq2011.0123

[53] Mizuta, K., Matsumoto, T., Hatate, Y., Nishihara, K. and Nakanishi, T. (2004) Removal of Nitrate-Nitrogen from Drinking Water Using Bamboo Powder Charcoal. Bioresource Technology, 95, 255-257. http://dx.doi.org/10.1016/j.biortech.2004.02.015 
Scientific Research Publishing (SCIRP) is one of the largest Open Access journal publishers. It is currently publishing more than 200 open access, online, peer-reviewed journals covering a wide range of academic disciplines. SCIRP serves the worldwide academic communities and contributes to the progress and application of science with its publication.

Other selected journals from SCIRP are listed as below. Submit your manuscript to us via either submit@scirp.org or Online Submission Portal.
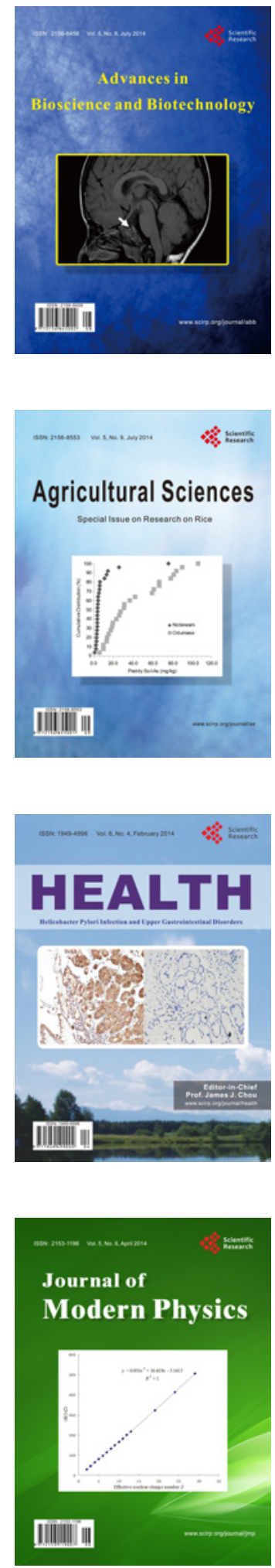
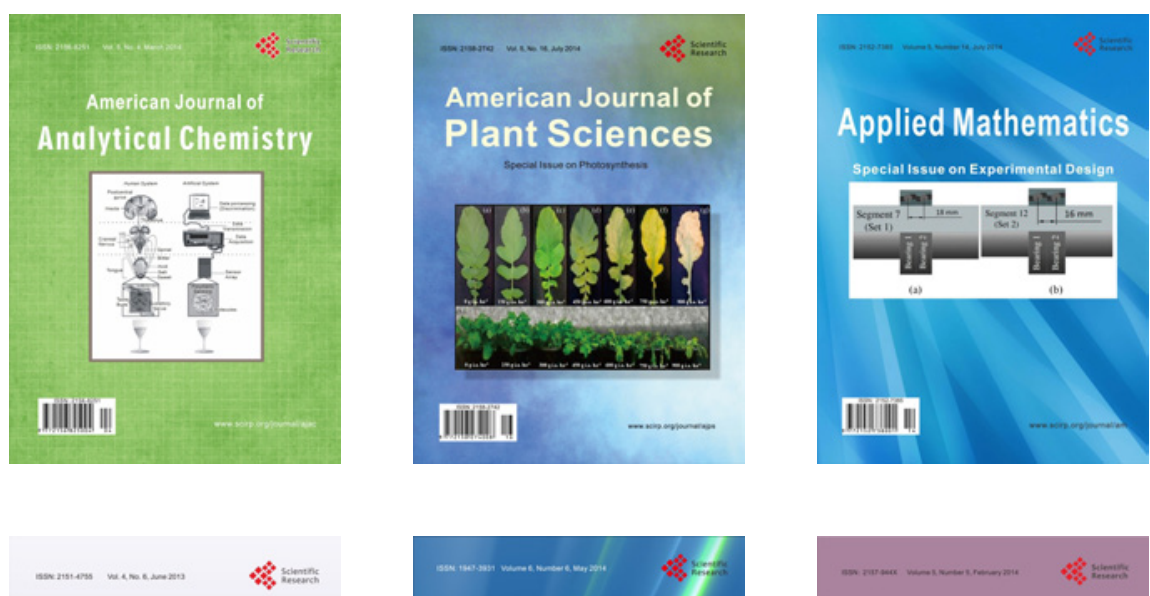

Creative Education
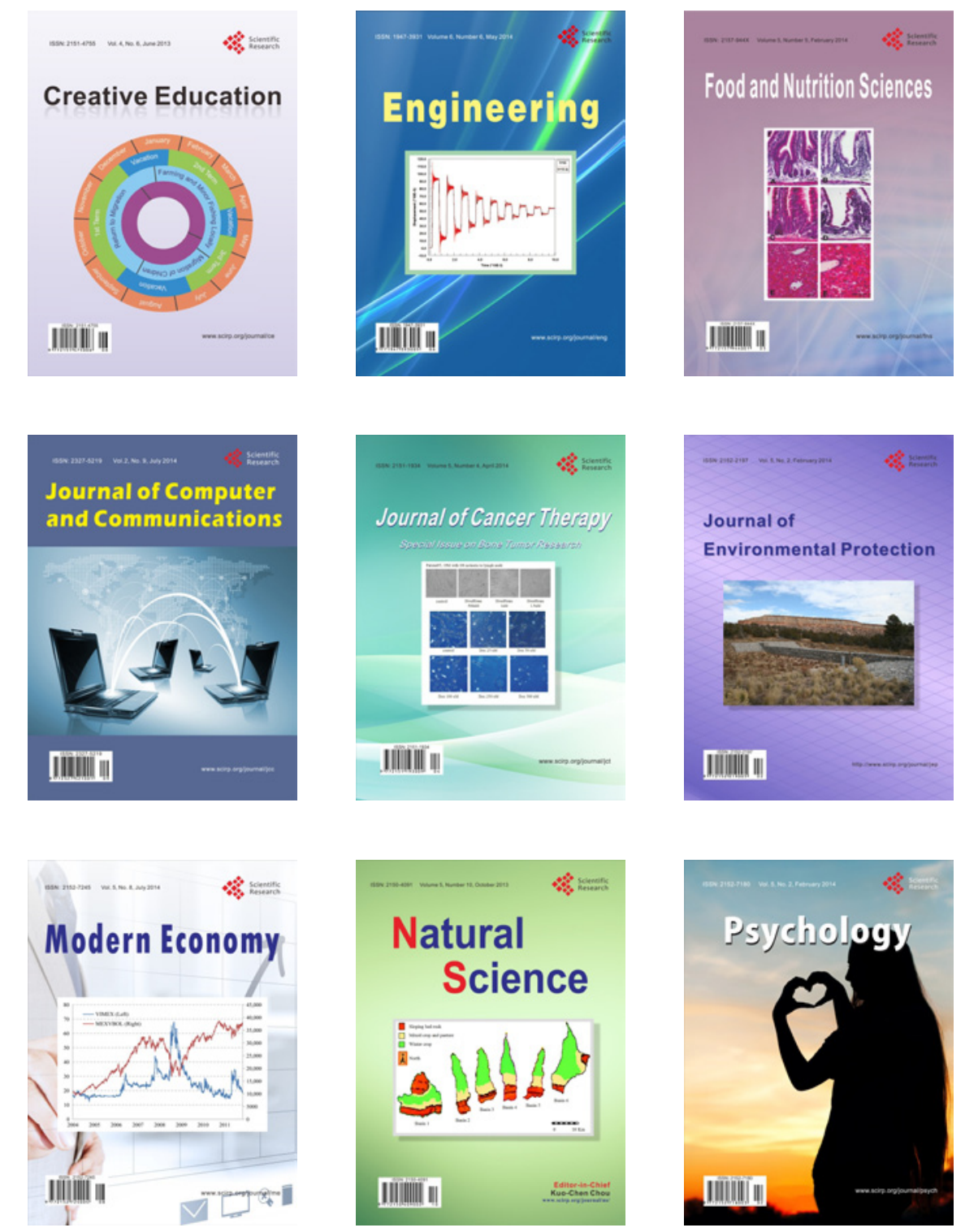